\title{
CORRELATION OF THE INDICATORS OF HIGH PERFORMANCE WOMEN BASKETBALL PLAYERS' GAME CHARACTERISTICS WITH PHYSICAL DEVELOPMENT AND PHYSICAL FITNESS
}

\author{
Rūtenis Paulauskas', Mindaugas Balčiūnas² \\ Vilnius Pedagogical University', Vilnius, Lithuania \\ Lithuanian Academy of Physical Education ${ }^{2}$, Kaunas, Lithuania
}

\begin{abstract}
Research background and hypothesis. Indicators of physical fitness and physical development influence individual performance results.

Research aim was to identify correlation between basketball performance indicators and physical development and fitness.

Research methods. The basketball players $(\mathrm{n}=12)$ of the Lithuanian National Women's Basketball Team were investigated. The performance indicators of this team were analyzed on the basis of data collected during the European Basketball Championship. During competition period the indicators of physical development and physical fitness of female basketball players were measured. Mathematical statistics methods were applied for the analysis of the research data. Pearson's correlation coefficients were applied to identify correlations among the indicators.

Research results. The correlations of the number of blocks with height, body mass, standing reach and psychomotor response were established. This indicator of game performance was technically simple and its efficiency was determined by good physical development and fast psychomotor reaction. The correlations of shooting percentage of different throws with physical fitness were different.

Discussion and conclusions. The shooting percentage of 2-point field goals correlated with muscle mass, body mass and take-off duration. This allows suggesting that a certain number of shots are performed after the physical contact with an opponent and jumping faster during the moment of throw. No correlation was established between 3-point field goals, free throws and physical fitness indicators. This means that shooting percentage was influenced by other factors. Steals, turnovers and passes, as complex technical and tactical actions, did not correlate with the researched physical fitness indicators.
\end{abstract}

Keywords: shot, jump, height, block, power.

\section{INTRODUCTION}

$\mathrm{T}$ The activity of basketball players during play is determined by a big number of factors. Both researchers and practitioners make attempts to identify components of players' preparation that predetermine good result of match. Statistical indicators of the competitions alone are not enough for a deeper insight into the process of elite basketball players' training. $\mathrm{T}$. O. Bompa and G. G. Haff (2009) argue that the quality of technical and tactical actions in game sports is mainly conditioned by physical fitness of players. However, coaches frequently raise the question: which component of training content is the most relevant technical, physical, tactical or psychological preparation?

The research on physical fitness and physical development of the best Lithuanian basketball players has been conducted (Balčiūnas et al., 
2009). Similar research on young basketball players' adaptation to physical load and its evaluation has also been carried out (Paulauskas et al., 2009 a). Other researchers (Mendes, Janeira, 2001; Sampaio et al., 2004; Reano et al., 2006) investigated the effect of technical actions (throws, passes, rebounds and others) on the achievements during competitive performance. J. Sampaio and M. Janeira (2003) analyzed other factors, i. e. the venue of the match and the stage of competitions. Analyzing statistical indicators of winning and losing teams, the researchers also made attempts to identify defence and tactical actions, which have crucial effect on the result of the match (Tavares, Gomes, 2003; Tsamourtzis et al., 2005).

Thus, training of a basketball team and results it achieves is an outcome of a multisided pedagogical, psychological, social, technical and tactical process which asks for a deep cognition and analysis. This work aims at getting an insight into the interaction of the aforesaid components: how indicators of physical fitness and physical development influence individual performance results. The aim of the study was to identify correlation between basketball performance indicators and physical development and physical fitness

\section{RESEARCH METHODS}

The basketball players $(\mathrm{n}=12)$ of the Lithuanian National Women's Basketball Team were investigated: the mean age $(\bar{x} \pm \mathrm{s})$ of the players was $25.8 \pm 4.1$ years and their average training experience totaled $12.8 \pm 3.9$ years. The performance indicators of this team were analyzed on the basis of data collected during the qualifying round to European Basketball Championship and playing in the 2009 European Women Basketball Championship. The research focused on 14 official games: seven victories and seven losses. The research data was based on official score sheets, which are available from official website of European Women Basketball Championship at www.fibaeurope.com.

The following indicators of competition performance were analysed:

- 2 point field goals (2P FG\%);

- 3 point field goals (3P FG\%);

- Free throws (FT\%);

- Rebounds in offence (Re);

- Assists (As);

- Personal fouls (PF);

- Turnovers (TO);
- Steals (St);

- Blocks (Bl).

During competition period the indicators of physical development of female basketball players were measured: height, body mass, arm grip. The research on players' physical fitness focused on: jump height while taking off with both legs and swinging with both hands, take-off duration, single muscular contraction power (SMCP) (Bosco et al., 1983), anaerobic alactic muscular power (AAMP) (Margaria et al., 1966). Combined anaerobic alactic power in a 30 -s veloergometer test was investigated (Wingate test) (Bar-Or, 1987). Psychomotor response time (PRT) to light stimulus and 10-s movement frequency (MF) were also measured (Skernevičius et al., 2004).

Mathematicalstatistics methods were applied for the analysis of the research data: the mathematical means were calculated $(\bar{x})$ and their biases $(\mathrm{S} \bar{x})$, standard deviation $(S)$, dispersion were evaluated according to variation coefficient $(V)$, dispersion area according to Min and Max values. Pearson's correlation coefficients (r) was applied to identify correlations among the indicators considering that $\mathrm{p}<0.05$, when $\mathrm{r}=0.532$. The data were processed using Statistica for Windows software package.

\section{RESEARCH RESULTS}

The Lithuanian National Women's Basketball Team won $50 \%$ of the matches played in the European Women's Basketball Championship and the qualifying round to European Basketball Championship. Indicators of player's performance are presented in Table 1. Shooting percentage of 2 point and 3 point field goals was low among separate players and on the average in the team. The evaluation of the dispersion of these two indicators showed the following: $\mathrm{V}=21.8 \%$ for 2 point shots, whereas dispersion of 3 point field goals totaled $\mathrm{V}=82.83 \%$. The research revealed the difference in technical preparedness of the players and in contribution of players in separate positions to the final result of the match. The team demonstrated the average percentage of free throws but its spread around the mean was large, i. e. $V=75.41 \%$. The dispersion area regarding free throws ranged from $100 \%$ to $45 \%$.

Large dispersion was observed in the parameters of rebounds. The average indicators were not high and the variation coefficient totaled $60.2 \%$.

The following parameters of competitive performance directly influenced the results of 
Table 1. Statistical indicators of competition performance of high level female basketball players

\begin{tabular}{|c|c|c|c|c|c|c|c|c|c|}
\hline Indices & 2P FG\% & 3P FG\% & FT \% & Re & As & PF & To & St & BI \\
\hline $\bar{X}$ & 38.05 & 27.40 & 75.32 & 3.83 & 1.53 & 2.14 & 1.58 & 0.79 & 0.48 \\
\hline$S \bar{x}$ & 2.62 & 7.18 & 4.79 & 0.73 & 0.28 & 0.30 & 0.29 & 0.17 & 0.23 \\
\hline S & 8.29 & 22.70 & 15.13 & 2.31 & 0.87 & 0.93 & 0.91 & 0.55 & 0.72 \\
\hline V\% & 21.80 & 82.83 & 20.09 & 60.20 & 56.98 & 43.62 & 57.61 & 69.70 & 150.81 \\
\hline Min & 25 & 0 & 45 & 1 & 0.5 & 0.8 & 0.2 & 0.3 & 0 \\
\hline Max & 50 & 75 & 100 & 7 & 3.5 & 3.8 & 3.5 & 1.8 & 2.4 \\
\hline
\end{tabular}

Table 2. Indicators of physical development and physical fitness of female basketball players during competition period

\begin{tabular}{|c|c|c|c|c|c|c|c|c|c|c|}
\hline Indices & $\begin{array}{c}\text { Height, } \\
\mathbf{c m}\end{array}$ & $\begin{array}{c}\text { Body } \\
\text { mass, } \\
\mathbf{k g}\end{array}$ & $\begin{array}{c}\text { Arm } \\
\text { grip, } \\
\mathbf{k g}\end{array}$ & $\begin{array}{c}\text { Jump } \\
\text { height, } \\
\mathbf{c m}\end{array}$ & $\begin{array}{c}\text { Take } \\
\text { off, } \\
\mathbf{m s}\end{array}$ & $\begin{array}{c}\text { SMCP, } \\
\mathbf{W}\end{array}$ & $\begin{array}{c}\text { AAMP, } \\
\mathbf{W}\end{array}$ & $\begin{array}{c}\text { PRT, } \\
\mathbf{m s}\end{array}$ & $\begin{array}{c}\text { MF, } \\
\mathbf{t} / \mathbf{1 0} \text { s }\end{array}$ & $\begin{array}{c}\text { Wingate } \\
\text { Test, } \\
\mathbf{W}\end{array}$ \\
\hline $\bar{X}$ & 181.9 & 72.1 & 37.9 & 46.70 & 206.80 & 1592.20 & 1050.3 & 171.5 & 77.4 & 508.9 \\
\hline$S \bar{x}$ & 2.66 & 2.42 & 2.06 & 1.27 & 9.01 & 87.04 & 29.51 & 2.96 & 2.33 & 13.99 \\
\hline $\mathrm{S}$ & 8.40 & 7.64 & 6.51 & 4.03 & 28.49 & 275.24 & 93.33 & 9.37 & 7.37 & 44.25 \\
\hline $\mathrm{V} \%$ & 4.62 & 10.60 & 17.17 & 8.63 & 13.78 & 17.29 & 8.89 & 5.46 & 9.52 & 8.70 \\
\hline Min & 170 & 62.5 & 24 & 40 & 154 & 1176 & 893 & 154 & 69 & 440 \\
\hline Max & 194 & 85 & 47 & 54 & 246 & 2059 & 1172 & 188 & 91 & 563 \\
\hline
\end{tabular}

matches. Very large dispersion around the mean was characteristic of passes, mistakes, fouls and blocks.

Evaluating indicators of physical development and physical fitness it can be observed that their spread is considerably lower around the mean compared to that of parameters of competitive performance (Table 2). The average height of the players was $181.9 \mathrm{~cm}$ and their dispersion was only $\mathrm{V}=4 \%$, body mass totaled $72.1 \mathrm{~kg}$ and demonstrated low dispersion as well $(\mathrm{V}=10.6 \%)$. The average dispersion around the mean was observed in indicators of arm grip, take-off duration and single muscular contraction power. The dispersion of other parameters around the mean was low and did not exceed $10.15 \%$.

We found competitive performance indicators which correlated with physical development and physical fitness parameters (Table 3). 2 point shooting percentage correlated with arm grip $\mathrm{r}=0.610$ and anaerobic alactic muscular power $\mathrm{r}=0.569$. The number of rebounds related to body mass $r=0.556$, and to psychomotor response time $\mathrm{r}=-0.555$. The inter-correlation of these indicators was statistically reliable.

It was established that the number of personal fouls negatively correlated with SMCP $\mathrm{r}=-0.543$. More powerful single muscle contraction may result in a smaller number of fouls.

The number of blocks had a strong correlation with height $r=0.698$, standing reach, body mass $r=0.755$ and psychomotor response time $r=-0,776$.

\section{DISCUSSION}

The correlation of basketball players' physical development and physical fitness indicators have already been established in our earlier research (Paulauskas et al., 2009 b). Therefore, this study is targeted not only at identification of correlation among physical development, physical fitness and competitive performance indicators but also at search for reasons. Our investigated average indicators of the team (Tables 1 and 2) are objective criteria for preparedness of female basketball players during competitive period. The dispersion of players' preparedness in the sample (the Lithuanian National Team) was also evaluated. It is important to mention that the dispersion of a big number of the investigated indicators is large, whereas indicators of physical fitness are dispersed less. This shows that physical fitness was developed applying physical loads of the same volume and that selection to the team was conducted according to the objective criteria. The large dispersion of competitive performance indicators is conditioned by a big number of factors: opponent's activity, psychological condition, tactical preparedness, physical fitness, etc. This research is mainly targeted at identification of correlations among physical development, functional capacity and competitive performance. 


\begin{tabular}{|c|c|c|c|c|c|c|c|c|c|c|c|c|c|c|c|c|c|c|c|c|}
\hline 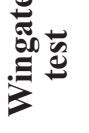 & $\stackrel{2}{2}$ & & & & & & & & & & & & & & & & & & & - \\
\hline$\sum$ & $\stackrel{\infty}{\sim}$ & & & & & & & & & & & & & & & & & & - & 吉 \\
\hline$\overline{\underline{a}}$ & $=$ & & & & & & & & & & & & & & & & & - & $\begin{array}{l}\bar{z} \\
0 \\
0\end{array}$ & 总 \\
\hline$\sum_{4}^{0}$ & 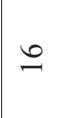 & & & & & & & & & & & & & & & & - & o & خे & $\stackrel{\infty}{?}$ \\
\hline$\sum_{i=1}^{\tilde{U}}$ & $\cong$ & & & & & & & & & & & & & & & - & $\underset{\stackrel{0}{R}}{\stackrel{0}{0}}$ & $\begin{array}{l}\overrightarrow{0} \\
n \\
0 \\
i\end{array}$ & $\begin{array}{l}n \\
0 \\
\tilde{o} \\
0\end{array}$ & $\frac{0}{3}$ \\
\hline 选 & \pm & & & & & & & & & & & & & & - & \begin{tabular}{l}
0 \\
\multirow{+}{*}{} \\
0
\end{tabular} & $\vec{\sigma}$ & $\stackrel{\Xi}{=}$ & $\begin{array}{l}n \\
o \\
q \\
o\end{array}$ & $\begin{array}{l}n \\
o \\
q \\
o\end{array}$ \\
\hline 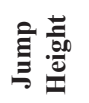 & $\stackrel{m}{\sim}$ & & & & & & & & & & & & & - & ñ & $\begin{array}{l}n \\
0 \\
0 \\
0 \\
0\end{array}$ & $\begin{array}{l}\hat{0} \\
n \\
0 \\
0\end{array}$ & $\frac{O}{0}$ & $\begin{array}{l}\text { S. } \\
0 \\
0\end{array}$ & $\begin{array}{l}\stackrel{\hat{\vartheta}}{\hat{n}} \\
\stackrel{1}{\varphi}\end{array}$ \\
\hline 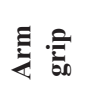 & $\simeq$ & & & & & & & & & & & & - & 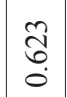 & $\begin{array}{l}\hat{n} \\
0 \\
0\end{array}$ & $\begin{array}{l}\hat{0} \\
0 \\
0\end{array}$ & $\begin{array}{l}\hat{\infty} \\
\hat{\infty} \\
0 \\
0\end{array}$ & ڤે & $\begin{array}{l}8 \\
\text { กุ } \\
0\end{array}$ & 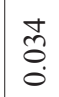 \\
\hline 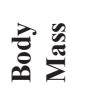 & $=$ & & & & & & & & & & & - & ڤ̆ & 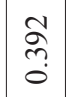 & ? & $\begin{array}{l}\infty \\
\stackrel{\infty}{p} \\
\stackrel{9}{0}\end{array}$ & $\begin{array}{l}\hat{0} \\
\hat{0}\end{array}$ & $\begin{array}{l}\bar{\sigma} \\
0 \\
0\end{array}$ & 官 & $\overrightarrow{5}$ \\
\hline 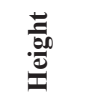 & 으 & & & & & & & & & & - & $\begin{array}{c}\widetilde{\partial} \\
\alpha \\
0 \\
0\end{array}$ & $\begin{array}{l}\overrightarrow{0} \\
\vdots \\
0\end{array}$ & ڤ్̀̆ & 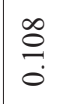 & \begin{tabular}{l}
0 \\
\multirow{1}{1}{} \\
0 \\
0
\end{tabular} & $\begin{array}{l}\vec{s} \\
\dot{0} \\
\dot{0}\end{array}$ & $\begin{array}{l}2 \\
\stackrel{2}{p} \\
\dot{q}\end{array}$ & $\overrightarrow{8}$ & \begin{tabular}{l}
0 \\
\multirow{2}{0}{} \\
0
\end{tabular} \\
\hline $\bar{m}$ & $a$ & & & & & & & & & - & 离 & 嗱 & $\overrightarrow{8}$ & $\frac{n}{2}$ & 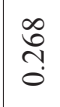 & 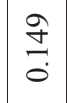 & 京 & 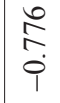 & $\stackrel{2}{=}$ & $\hat{\tilde{n}}$ \\
\hline $\bar{\omega}$ & $\infty$ & & & & & & & & - & $\begin{array}{l}\tilde{\theta} \\
\hat{\sigma} \\
\dot{\varphi}\end{array}$ & $\begin{array}{l}2 \\
0 \\
0 \\
0 \\
1\end{array}$ & $\overrightarrow{0}$ & $\vec{f}$ & तె & 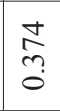 & \begin{tabular}{l}
\multirow{i}{*}{} \\
$\stackrel{0}{i}$ \\
\end{tabular} & $\begin{array}{l}\stackrel{2}{a} \\
\stackrel{0}{0} \\
0\end{array}$ & $\begin{array}{l}0 \\
8 \\
0\end{array}$ & $\frac{n}{7}$ & $\begin{array}{l}\text { ते } \\
\stackrel{2}{1}\end{array}$ \\
\hline 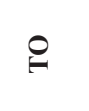 & $r$ & & & & & & & - & $\begin{array}{l}8 \\
0 \\
0 \\
0\end{array}$ & $\stackrel{n}{m}$ & 苦 & $\stackrel{+}{m}$ & $\begin{array}{l}0 \\
8 \\
0 \\
0\end{array}$ & 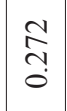 & $\hat{\widehat{3}}$ & $\begin{array}{l}n \\
o \\
+ \\
0\end{array}$ & $\begin{array}{l}n \\
0 \\
0 \\
0 \\
0\end{array}$ & m & $\frac{\infty}{0}$ & $\begin{array}{l}\vec{\infty} \\
\stackrel{+}{+} \\
\dot{\varphi}\end{array}$ \\
\hline$\stackrel{5}{2}$ & 0 & & & & & & - & $\stackrel{n}{2}$ & ?े & ڤ̊. & $\stackrel{m}{m}$ & $\overrightarrow{\bar{\jmath}}$ & $\underset{\infty}{\infty}$ & $\begin{array}{l}\vec{\infty} \\
\overrightarrow{0}\end{array}$ & o & $\begin{array}{l}\tilde{n} \\
\tilde{n} \\
i\end{array}$ & 辛 & $\begin{array}{l}0 \\
2 \\
3 \\
0\end{array}$ & 守 & 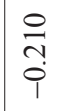 \\
\hline$\frac{y}{4}$ & in & & & & & - & $\frac{d}{0}$ & o̊ & 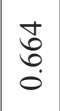 & $\underset{\stackrel{a}{+}}{\stackrel{9}{i}}$ & 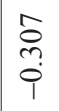 & 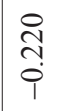 & $\underset{⿱ 亠}{\Delta}$ & $\frac{0}{3}$ & 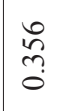 & $\begin{array}{l}\vec{\infty} \\
\stackrel{9}{i}\end{array}$ & $\begin{array}{l}\overrightarrow{\vec{N}} \\
\stackrel{9}{i}\end{array}$ & $\stackrel{\infty}{\stackrel{\infty}{0}}$ & $\begin{array}{l}\infty \\
n \\
n \\
0\end{array}$ & 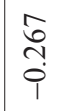 \\
\hline$\approx$ & $\nabla$ & & & & - & ? & त̂. & oे & 움 & $\begin{array}{l}\infty \\
n \\
n \\
0\end{array}$ & 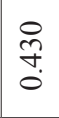 & $\frac{2}{\tilde{n}}$ & 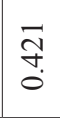 & $\begin{array}{l}0 \\
0 \\
0 \\
0 \\
\end{array}$ & $\frac{n}{7}$ & $\underset{0}{\stackrel{\Xi}{二}}$ & $\begin{array}{l}\overrightarrow{0} \\
\dddot{n} \\
0\end{array}$ & $\begin{array}{l}n \\
n \\
n \\
0 \\
1\end{array}$ & $\begin{array}{l}8 \\
8 \\
0 \\
0\end{array}$ & $\begin{array}{c}\overrightarrow{0} \\
0 \\
0\end{array}$ \\
\hline 5 & $m$ & & & - & $\begin{array}{l}0 \\
0 \\
0 \\
9\end{array}$ & $\hat{n}$ & $\begin{array}{l}n \\
0 \\
0 \\
0\end{array}$ & $\frac{8}{0}$ & 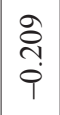 & $\begin{array}{l}\vec{r} \\
\dot{\infty} \\
\dot{9}\end{array}$ & $\mid \begin{array}{l}2 \\
0 \\
0 \\
\dot{\varphi}\end{array}$ & $\underset{\stackrel{R}{i}}{\stackrel{0}{0}}$ & $\begin{array}{l}n \\
0 \\
0 \\
0\end{array}$ & $\begin{array}{l}0 \\
\dot{7} \\
\dot{9}\end{array}$ & $\frac{\infty}{n}$ & 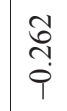 & \begin{tabular}{l}
2 \\
\multirow{2}{0}{} \\
$\stackrel{9}{9}$
\end{tabular} & $\overrightarrow{\widehat{a}}$ & $\frac{8}{0}$ & $\overrightarrow{0}$ \\
\hline లి & $N$ & & - & 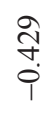 & $\begin{array}{l}\infty \\
\hat{\sigma} \\
0 \\
0\end{array}$ & ঐे & तิ & 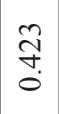 & ồ & 足 & $\frac{\overrightarrow{0}}{0}$ & $\begin{array}{l}8 \\
\stackrel{0}{0} \\
1 \\
0\end{array}$ & 满 & ? & ?̂. & oे & $\vec{m}$ & 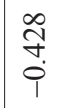 & ơ & 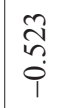 \\
\hline ڤิ & - & - & $\stackrel{\infty}{\stackrel{\infty}{0}}$ & $\begin{array}{l}0 \\
0 \\
n \\
0 \\
0\end{array}$ & 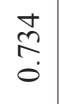 & ồ & $\frac{n}{n}$ & $\underset{⿱}{+}$ & 㕝 & तิ & ஓे. & 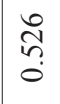 & $\stackrel{0}{0}$ & $\begin{array}{l}\mathfrak{Z} \\
0 \\
0\end{array}$ & $\frac{n}{3}$ & $\stackrel{n}{\hat{n}}$ & $\begin{array}{l}0 \\
\hat{\circ} \\
0\end{array}$ & $\frac{\mathcal{J}}{\dot{T}}$ & $\vec{\Xi}$ & \begin{tabular}{l}
0 \\
\multirow{0}{0}{} \\
0
\end{tabular} \\
\hline$\dot{z}$ & & - & 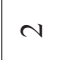 & $n$ & $\nabla$ & in & 0 & $r$ & $\infty$ & $a$ & $\circ$ & $=$ & $\simeq$ & $\cong$ & \pm & $\cong$ & 0 & $=$ & $\stackrel{\infty}{-}$ & $\approx$ \\
\hline
\end{tabular}


The percentage of shooting is a complex coordination action, which has a considerable effect on the final result of the match. It was established that the percentage of 2 point field goals shooting correlated with body mass. As it is widely known, the majority of 2 point field goals are scored from the three seconds zone, where physical contact with opponent occurs; therefore, players of bigger body mass and muscle mass in particular achieve better results. One more indicator, which links $(r=0.543)$ with the shooting percentage of 2 point field goals is take-off duration. The majority of basketball players make a jump shot. Therefore we assume that this important functional indicator may condition an advantage over an opponent, and, thus, result in a better shooting percentage.

It was established that the shooting percentage of 3-point field goals is not related to indicators of physical fitness and physical development. Differently from 2-point field goals, female basketball players take 3 points not at a jump but standing, therefore take-off is not relevant in this situation. This complicated technical action is affected by other factors. Free throws do not correlate with the researched indicators of physical fitness. It is assumed that psychological condition and ball throwing technique have bigger effect on these elements of competitive activity (Vaughn et al., 1994).

The correlation of body mass with rebounds $(r=0.572)$ (Figure 1) may be explained by the fact that a player in a better position may rebound the ball. Therefore, bigger body mass may positively effect the fight for a better position close to the basket. Particular attention should be paid to the correlation between psychomotor response time and the number of rebounds $(r=-0.555)$. This proves that to make a fast movement towards a bound ball, psychomotor response time is of utmost importance. In fact, the reliability of this correlation is not very strong; therefore we assume that other factors (location of a player, techniques) are very important to this competitive element (Sampaio, Janeira, 2003). The correlations were identified between the number of rebounds and anaerobic alactic muscular power. It can be concluded that power of short-tem muscle work, which enables to lift the body mass into a certain height as well as to change the direction of movement, to perform repeated high-amplitude movements, play an important role.

It should be pointed out that no reliable correlation was observed among the number of rebounds, jump height and take-off duration. We think that this is a specific feature of women's basketball, where the taken position - blocking technique and standing reach play - are of considerable importance. The number of rebounds did not correlate with the height of players, which showed that the height is not a decisive factor fighting for rebounds.

It has been established that the number of successful passes does not correlate with physical development and fitness indicators and that it is a result of fast tactical thinking.

The analysis of correlation links revealed that the correlation of the number of personal fouls,
Figure 1. The correlation of body mass with rebounds

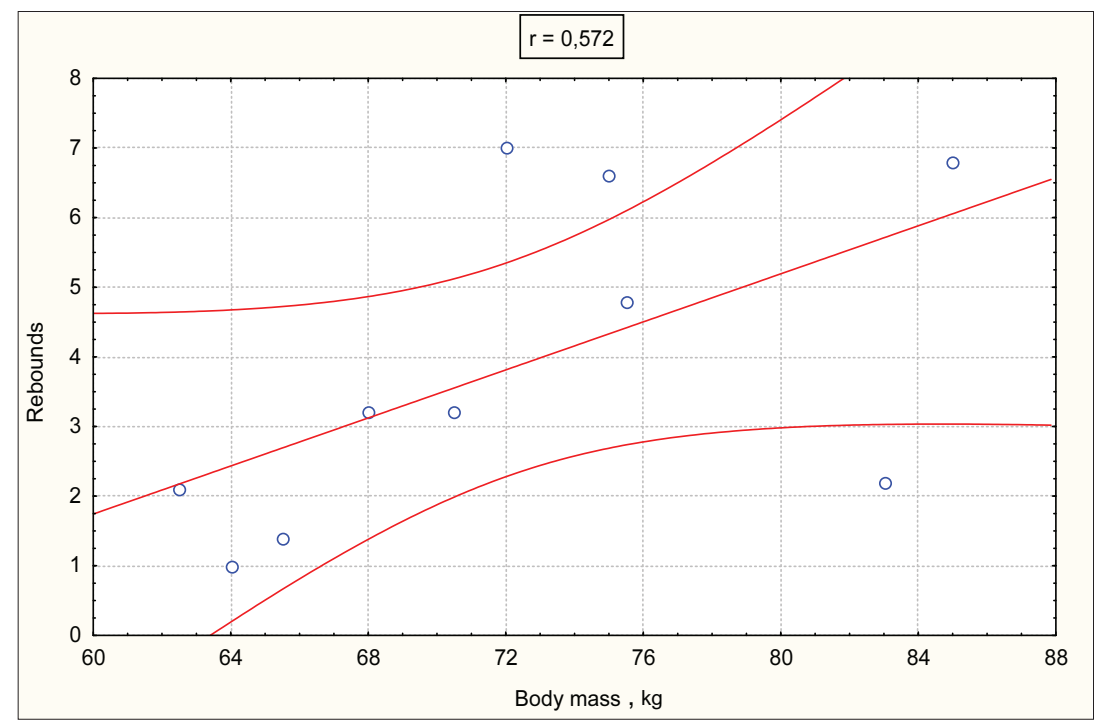



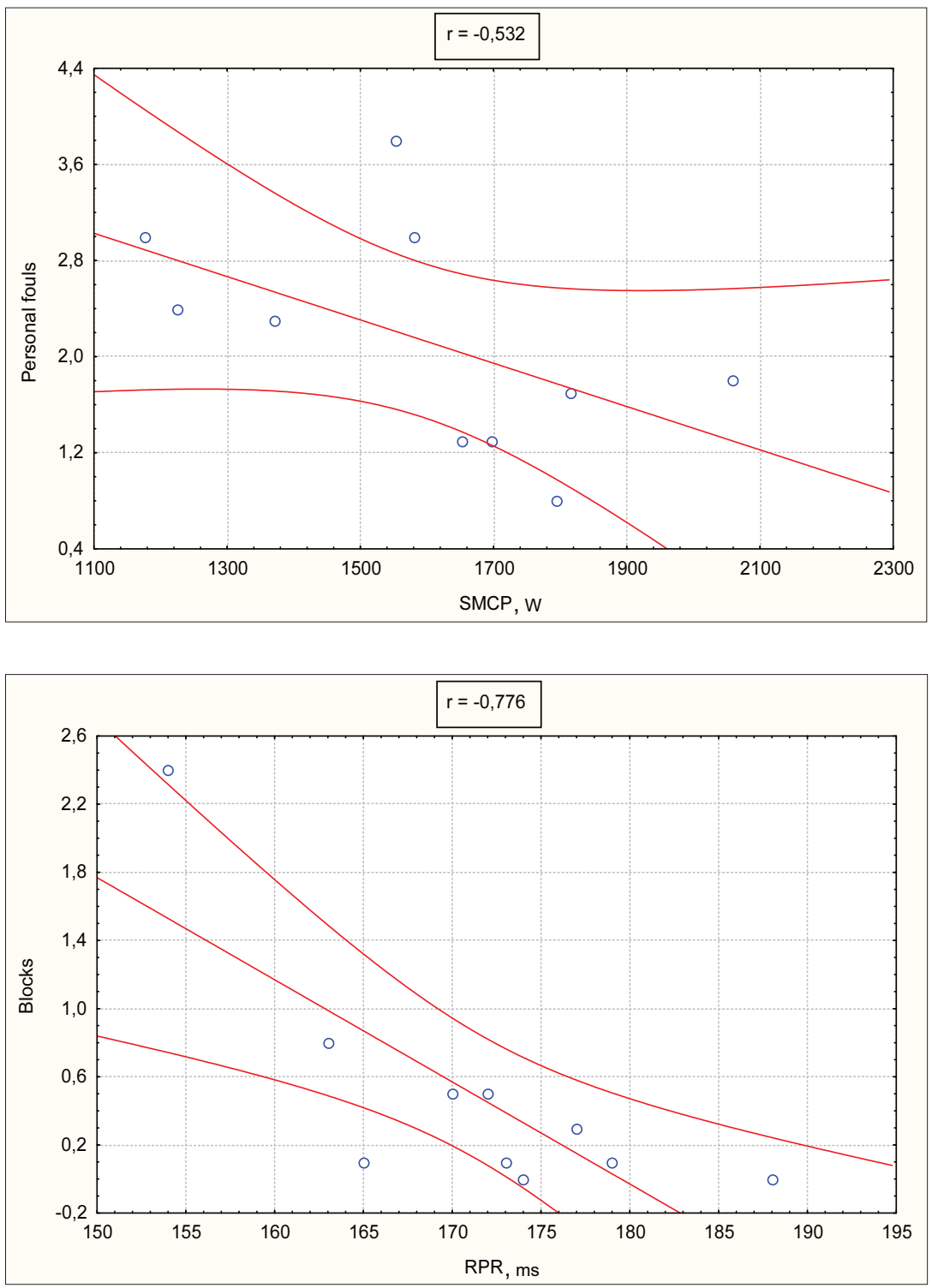

Figure 2. The correlation of the number of personal fouls and single muscular contraction power

Figure 3. The correlation of number of blocks and psychomotor response time muscle contraction speed and single muscular contraction power exists (Figure 2). A conclusion can be drawn that a player with higher SMCP (single muscle contraction power) will manage to more successfully defend avoiding personal fouls. This action requiring lower technical and tactical preparedness, i. e. fast moving without a ball, reflects its direct link to fast muscle functional parameters (Pim, 1986).

No correlation was established between the number of turnovers, steals and physical fitness parameters investigated previously. This depends on technical and tactical preparedness (Lidor, Arnon, 2000).

The number of blocks shows a large dispersion around the mean. The correlative analysis revealed that this technically simple action had a strong link with height, hand reach, body mass, muscle mass and psychomotor response time (Figure 3). This proves that the hand movement is more exact when psychomotor response time is shorter.

It is thought that height is one of the major factors playing basketball (Wissel, 2004). However, our research showed that the height of female basketball players did not correlate with other competitive performance indicators (except blocks). This means that higher players need good physical fitness to perform individual game actions.

Frequently a lot of attention is paid to power development during training sessions. It has been established that static power does not relate to competitive performance indicators.

The research revealed that jump height, function of central nerve system liability expressed through movement frequency for $10 \mathrm{~s}$, agility, $30-\mathrm{s}$ veloergometer tests at maximum power did not correlate. 


\section{CONCLUSIONS AND PERSPECTIVES}

1. The correlation of the number of blocks with height, body mass, standing reach and psychomotor response was established. This indicator of competitive performance is technically simple and its efficiency is determined by good physical development and fast psychomotor reaction.

2. The correlation of shooting percentage of different throws with physical fitness is different. The shooting percentage of 2-point field goals correlates with muscle mass, body mass and takeoff duration. This allows for conclusions that a certain number of shots are performed after the physical contact with an opponent and jumping faster during the moment of throw. No correlation has been established between 3-point field goals, free throws and physical fitness indicators. This means that shooting percentage is influenced by other factors.

3. It has been established that the number of rebounds depends not on the height of a player but correlates with body mass and functional muscular features: speed and power of muscle contraction. Psychomotor response time is of utmost importance to the number of rebounds in offence.

4. Steals, turnovers and passes, as complex technical and tactical actions, do not correlate with the researched physical fitness indicators.

5. It can be concluded that a player with bigger SMCP will be able to more successfully defend, to take better position in defence and to avoid personal fouls because the correlation is established among the aforesaid indications.

\section{REFERENCES}

Balčiūnas, M., Garastas, V., Stonkus, S. (2009). Krepšininku parengtumas: nustatymas ir juertinimas: studiju knyga. Kaunas: LKKA, LKF.

Bar-Or., O. (1987). The Wingate anaerobic test. An update on methodology, reliability and validity. Sports Medicine, 28, 35-39.

Bompa T. O., Haff G. G. (2009). Periodization: Theory and Methodology of Training ( $5^{\text {th }}$ ed.). US.: Human Kinetics. Champain IL.

Bosco, C., Komii, P., Tihanyi, J., Fekete, C., Apor, P. (1983). Mechanical power test and fiber composition of human leg extensor muscles. European Journal of Applied Physiology. 51, 129-135.

Lidor, R., Arnon, M. (2000). Developing indexes of efficiency in basketball: Talk with the coaches in their own language. Kinesiology, 32 (2), 31-41.

Margaria, R., Aghemo, P., Rovelli, E. (1966). Mearsument of muscular power (anaerobic) in man. European Journal of Applied Physiology. 21, 16621664.

Mendes, L., Janeira, M. (2001). Basketball performancemultivariate study in Portuguese professional male basketball teams. In Notational Analysis of Sport IV (pp. 103-111). Cardiff: UWIC.

Paulauskas, R., Skernevičius, J., Paulauskienė, R. (2009 a). Ivairaus meistriškumo ir amžiaus krepšininkių fizinio išsivystymo, fizinių galiu bei funkcinių rodikliu lyginamoji analizè. Ugdymas. Kūno kultūra. Sportas, 2 (73), 86-91.

Paulauskas, R., Šatas, A., Paulauskienè, R. (2009 b). Moterų komandos krepšininkių fizinio išsivystymo, fiziniu ir funkciniu galiu sąsaja. Sporto mokslas, V, 1 (55), 24-28.
Pim, R. (1986). The effect of personal fouls on winning and losing basketball games. The Coaching Clinic, 24, 14-16.

Reano, G. M. A., Calvo, L. A., Toro, O. E. (2006). Differences between winning and losing under-16 male basketball teams. Performance Analysis of Sport VII (pp. 142-149). Cardiff: CPA Press, UWIC.

Sampaio, J., Godoy, S. I., Feu, S. (2004). Discriminative power of basketball game related statistics by level of competition and sex. Perceptual and Motor Skills, 99, 1231-1238.

Sampaio, J., Janeira, M. (2003). Statistical analysis of basketball team performance: Understanding teams' wins and losses according to a different index of ball possessions. International Journal of Performance Analysis in Sport, 3 (1), 40-49.

Skernevičius, J., Raslanas, A., Dadelienè, R. (2004). Sporto mokslo tyrimu metodologija. Vilnius: LSIC.

Tavares, F., Gomes, N. (2003). The offensive process in basketball - a study in high performance junior teams. International Journal of Performance Analysis in Sport, 3 (1), 27-33.

Tsamourtzis, E., Karypidis, A., Athanasiou, N. (2005). Analysis of fast breaks in basketball. International Journal of Performance Analysis in Sport, 5 (2), 17-22.

Vaughn, R. E., Kozar, B., Whitfield, K. E., Lord, R. J., Dye, B. (1994). Importance of free-throws at various stages of basketball games. Perceptual and Motor Skills, 78, 243-248.

Wissel. H. (2004). Basketball: Steps to Success (2 ${ }^{\text {nd }}$ ed.). Champaign, IL.: Human Kinetics. 


\title{
DIDELIO MEISTRIŠKUMO KREPŠININKIŲ ŽAIDIMO VEIKLOS IR FIZINIO IŠSIVYSTYMO BEI PAJĖGUMO RODIKLIŲ SĄSAJOS
}

\author{
Rūtenis Paulauskas', Mindaugas Balčiūnas ${ }^{2}$ \\ Vilniaus pedagoginis universitetas ${ }^{1}$, Vilnius, Lietuva \\ Lietuvos kūno kultūros akademija², Kaunas, Lietuva
}

\begin{abstract}
SANTRAUKA
Tyrimo pagrindimas ir hipotezė. Krepšininkių veikla aikštelëje priklauso nuo daugelio veiksnių. Manoma, kad fizinio pajègumo ir išsivystymo rodikliai veikia individualų žaidimo rezultatą.

Tikslas - ištirti didelio meistriškumo moterų krepšinio komandos žaidẻjų fizini išsivystymą bei pajègumą ir nustatyti koreliacinius ryšius su žaidimo veiklos rodikliais.

Metodai. Lietuvos moterų krepšinio rinktinès žaidèjų žaidimo rodiklių analizė atlikta tiriamosioms dalyvaujant atrankoje i Europos krepšinio čempionatą. Varžybų laikotarpiu buvo išmatuoti krepšininkių fizinio išsivystymo rodikliai. Ryšiams tarp rodiklių nustatyti skaičiuoti Pirsono koreliacijos koeficientai.

Rezultatai. Nustatyta, kad blokuotų metimų skaičius turi sąsajų su ūgio, kūno masės ir psichomotorinès reakcijos laiko rodikliais. Šis žaidimo veiklos rodiklis yra techniškai nesudètingas, todèl jo veiksmingumą lemia geras fizinis išsivystymas ir greita psichomotorinè reakcija. Skirtingų metimų tikslumo ir fizinio pajëgumo ryšys nevienodas.

Aptarimas ir išvados. Dvitaškių tikslumui turi itakos raumenų ir kūno masè bei pasispyrimo laikas šuolio metu. Tritaškių ir baudų metimai sąsajų su mūsų tirtais fizinio išsivystymo ir fizinio pajègumo rodikliais neturi. Vadinasi, jų tikslumą lemia kiti veiksniai. Krepšininkių atkovotų kamuolių skaičius priklauso ne nuo ūgio, o nuo kūno masès bei raumenų funkciniu ypatybių (susitraukimo greičio ir galingumo). Atkovotų kamuolių skaičiu puolant lemia psichomotorinès reakcijos laikas. Perimti kamuoliai, klaidos ir rezultatyvūs perdavimai, kaip sudètingi technikos ir taktikos veiksmai, sąsajų su mūsų tirtais fizinio pajègumo rodikliais neturi. Galima daryti prielaidą kad žaidèjas, turintis didesnị vienkartinị raumenų susitraukimo galinguma, galès sẻkmingiau gintis prieš varžova, užimti geresnę padètị gindamasis ir išvengti asmeninių pražangų, nes tarp šių rodiklių yra nustatytas koreliacinis ryšys.
\end{abstract}

Raktažodžiai: metimas, šuolis, ūgis, blokas, galingumas.

Gauta 2011 m. rugsèjo 10 d.

Received on September 10, 2011 